\title{
Risk Factors For Ectopic Pregnancy : A Case Control Study In Tertiary Care Centre
}

\author{
Dr. Bhavna ${ }^{1}$, Dr. K.B. Gupta ${ }^{2}$, Dr. K. Pathania ${ }^{3}$, Dr. Monika Jindal ${ }^{4}$, \\ Dr. Rashmi Vohra ${ }^{5}$, Dr.Mushtaq Ahmed ${ }^{6}$ \\ 1) SR OBG, MMMCH, Kumarhatti, Solan Vill. Jhagrial, P.O Bara, Tehsil Nadaun, Distt. Hamirpur, Himachal \\ Pradesh. PIN-177044 \\ 2) Prof. and Head of Department, MMMCH, Kumarhatti, Solan. \\ 3) Associate Prof. KNSH, IGMC,Shimla \\ 4) Assistant Prof. MMMCH, Kumarhatti, Solan \\ 5) SR OBGY, MMMIMSR, Mullana, Ambala. \\ 6) SR General Surgery, MMMCH, Kumarhatti, Solan.
}

\begin{abstract}
:
Objective: To study various risk factors for ectopic pregnancy among population of Himachal Pradesh.

Method: Present case control study was conducted over a period of one year in the Department of obstetrics and gynaecology, Kamla Nehru State Hospital for mother and child, Indira Gandhi Medical College , Shimla from March, 2011 to Feb, 2012. In this case control study, all the diagnosed cases of ectopic pregnancy were taken as cases and controls were the age matched women with normal intrauterine pregnancy of same gestation age. Total number of diagnosed ectopic pregnancy cases who reported to hospital during study period were 110. All cases were analysed.

Results: Overall incidence of ectopic pregnancy was 18.62 per 1,000 deliveries in the present study with mean age 28.72 years. Maximum number of cases were multigravidae (80.90\%). Eighty $(72.72 \%)$ cases belonged to rural area and $61.81 \%$ cases were from middle - lower socioeconomic status. Most common risk factors were infertility (23.60\%), PID (22.70\%), previous laparotomy (22.72\%), tubal sterilization (10\%) and previous history of ectopic pregnancy (10\%) in the present study.

Conclusion: Ectopic pregnancy still remains the most lethal obstetrical emergency and a very high index of suspicion in women with risk factors will reduce ectopic pregnancy related morbidity and mortality.
\end{abstract}

Key words: Ectopic pregnancy, infertility, mortality, PID, risk factors.

\section{Introduction}

Motherhood is a dream which every woman possesses universally and inherently. This dream of motherhood is not always pleasant but she may experience some nightmares through her journey. One of this is ectopic pregnancy which can be life threatening.

Although total number of pregnancies has declined over the past three decades but prevalence of ectopic pregnancies has increased from 4.5 per 1,000 pregnancies in 1970 to 19.7 per 1,000 pregnancies [1] in 1992.

Risk factors for ectopic pregnancy are strongly associated with conditions that cause alterations to the normal mechanism of fallopian tubal transport. It is postulated that the more damage that occurs to the fallopian tube, the higher the risk for developing an ectopic pregnancy.

Various risk factors like previous ectopic pregnancy, tubal corrective surgery, tubal sterilization, intrauterine devices, documented tubal pathology, infertility, assisted reproductive techniques, PID, smoking, prior abortions, multiple sexual partners and prior caesarean delivery have been implicated in the development of the ectopic pregnancy[2].

\section{Materials and methods}

Present study was conducted in Department of obstetrics and gynaecology, Kamla Nehru State Hospital for mother and child, Indira Gandhi Medical College, Shimla over a period of one year from March, 2011 to February, 2012. In this case control study, all the diagnosed cases of ectopic pregnancy were taken as cases and controls were the age matched women with normal intrauterine pregnancy of same gestation age.

All the patients with diagnosed ectopic pregnancy were admitted and history especially regarding risk factors was taken as per preset performa. A rapid initial assesssment of patient was made and cases managed accordingly. Detailed examination was performed. Data obtained was analysed by using chi square test and significant value was taken as $\mathrm{p}$ value $(\leq 0.05)$. 


\section{Observations}

Incidence of ectopic pregnancy was 18.62 per 1,000 deliveries.

TABLE 1: AGE DISTRIBUTION

\begin{tabular}{|c|c|c|c|c|c|}
\hline Age (in years) & $\begin{array}{l}\text { Study group } \\
\mathrm{N}=110\end{array}$ & $\%$ & $\begin{array}{l}\text { Control group } \\
\mathrm{N}=110\end{array}$ & $\%$ & $\mathrm{P}$ value \\
\hline$<20 \mathrm{yrs}$ & 01 & 0.90 & 04 & 3.63 & \multirow{7}{*}{0.10} \\
\hline $20-24 y r s$ & 23 & 20.90 & 19 & 17.27 & \\
\hline $25-29 y r s$ & 42 & 38.18 & 39 & 35.45 & \\
\hline $30-34 \mathrm{yrs}$ & 26 & 23.63 & 32 & 29.09 & \\
\hline $35-39 \mathrm{yrs}$ & 16 & 14.54 & 14 & 12.72 & \\
\hline$>40 \mathrm{yrs}$ & 02 & 1.81 & 02 & 1.81 & \\
\hline Total & 110 & 100 & 110 & 100 & \\
\hline
\end{tabular}

Study as well as control group were comparable according to age distribution.

TABLE 2: GRAVIDITY

\begin{tabular}{|l|c|c|c|c|}
\hline Gravidity & $\mathrm{N}=110$ & $\mathrm{~N}=110$ & $\%$ \\
\hline PGR & 21 & 19.09 & 21 & 19.09 \\
\hline GravidaII & 34 & 30.90 & 34 & 30.90 \\
\hline GravidaIII & 32 & 29.09 & 32 & 29.09 \\
\hline GravidaIV & 15 & 13.63 & 15 & 13.63 \\
\hline Gravida $\geq \mathrm{V}$ & 08 & 07.27 & 08 & 07.27 \\
\hline
\end{tabular}

Maximum number of the cases, $80.90 \%$ were MGR.

TABLE 3: RESIDENCE

\begin{tabular}{|l|l|l|l|l|l|l|l|}
\hline Rural/Urban & $\begin{array}{l}\text { Study group } \\
\mathrm{N}=110\end{array}$ & $\%$ & $\begin{array}{l}\text { Control } \\
\text { group } \\
\mathrm{N}=110\end{array}$ & $\%$ & OR & CI & P value \\
\hline Rural & 80 & 72.72 & 46 & 41.81 & \multirow{2}{*}{3.71} & $2.0,6.8$ & $<.0001$ \\
\hline Urban & 30 & 27.27 & 64 & 58.18 & 100.0 & & \\
\hline Total & 110 & 100.0 & 110 & 10 &
\end{tabular}

Chi-square value $=21.47, \mathrm{p}<.0001, \mathrm{OR}=3.71, \mathrm{CI}=(2.0,6.8)$

Eighty cases belonged to rural population in the study group and forty six cases belonged to rural population in the control group and the difference was highly significant statistically $(p<0.001)$.

TABLE 4: HISTORY OF SMOKING

\begin{tabular}{|l|l|l|l|l|l|l|}
\hline H/O Smoking & $\begin{array}{l}\text { Study group } \\
\mathrm{N}=110\end{array}$ & $\%$ & $\begin{array}{l}\text { Control group } \\
\mathrm{N}=110\end{array}$ & $\%$ & OR & P value \\
\cline { 1 - 5 } Smoker & 31 & 28.18 & 18 & 16.36 & & \\
\cline { 1 - 5 } Non smoker & 79 & 71.82 & 92 & 83.64 & & \\
\cline { 1 - 5 } & 110 & 100.00 & 110 & 100.00 & 2.00 & 0.03 \\
\hline
\end{tabular}

Chi square value $=3.2, \mathrm{p}=0.03$

Ectopic pregnancy was more common among smokers when compared to control group. The difference was statistically significant $(\mathrm{p}=0.03)$.

TABLE 5: HISTORY OF MULTIPLE SEXUAL PARTNERS

\begin{tabular}{|l|l|l|l|l|}
\hline H/o MSP & $\begin{array}{l}\text { Study group } \\
\mathrm{N}=110\end{array}$ & $\%$ & $\begin{array}{l}\text { Control group } \\
\mathrm{N}=110\end{array}$ & $\%$ \\
\hline Present & 07 & 6.36 & 00 & 00 \\
\hline Absent & 103 & 93.63 & 110 & 100 \\
\hline Total & 110 & 100.0 & 110 & 100 \\
\hline
\end{tabular}

There were only $7(6.36 \%)$ cases that came out with history of multiple sexual partners in the study group and none in the control group. 


\section{TABLE 6: PAST HISTORY OF PID}

\begin{tabular}{|c|c|c|c|c|c|c|c|}
\hline H/O PID & $\begin{array}{l}\text { Study group } \\
\mathrm{N}=110\end{array}$ & $\%$ & $\begin{array}{l}\text { Control } \\
\text { group } \\
\mathrm{N}=110\end{array}$ & $\%$ & OR & CI & $\mathrm{P}$ value \\
\hline Present & 25 & 22.70 & 04 & 03.64 & \multirow{3}{*}{7.79} & \multirow{3}{*}{$2.5,27.6$} & \multirow{3}{*}{0.001} \\
\hline Absent & 85 & 77.30 & 106 & 96.36 & & & \\
\hline Total & 110 & 100.0 & 110 & 100.0 & & & \\
\hline
\end{tabular}

Chi square $=17.5, \mathrm{p}=.001, \mathrm{OR}=7.79, \mathrm{CI}=(2.5,27.6)$

Past history of PID was present in 25(22.70\%) cases in the study group whereas 4 (3.64\%) cases in the control group. The difference was highly significant $(\mathrm{p}=0.001)$.

TABLE 7: PAST HISTORY OF INFERTILITY

\begin{tabular}{|l|l|c|l|l|l|l|l|}
\hline H/O Infertility & $\begin{array}{l}\text { Study group } \\
\mathrm{N}=110\end{array}$ & $\%$ & $\begin{array}{l}\text { Control group } \\
\mathrm{N}=110\end{array}$ & $\%$ & Odd ratio & CI & P value \\
\hline Present & 26 & 23.60 & 8 & 7.27 & \multirow{2}{*}{3.94} & \multirow{2}{*}{$1.8,11.0$} & $<0.001$ \\
\hline Absent & 84 & 76.40 & 102 & 92.72 & & \\
\hline Total & 110 & 100.0 & 110 & 100.0 & & & \\
\hline
\end{tabular}

Chi square value $=13.1, \mathrm{p}<0.001, \mathrm{OR}=3.94, \mathrm{CI}=(1.8,11.0)$

It was observed that the past history of infertility was present in $26(23.60 \%)$ cases in the study group and 8 $(7.27 \%)$ cases in the control group. The difference was highly significant $(\mathrm{p}<0.001)$.

TABLE 8: HISTORY OF USE OF OVULATION INDUCTION DRUGS

\begin{tabular}{|l|l|l|l|l|l|l|l|}
\hline $\begin{array}{l}\text { Ovulation induction } \\
\text { drugs }\end{array}$ & $\begin{array}{l}\text { Study } \\
\text { group } \\
\mathrm{N}=110\end{array}$ & $\%$ & $\begin{array}{l}\text { Control } \\
\text { group } \\
\mathrm{N}=110\end{array}$ & $\%$ & OR & CI & P value \\
\hline Present & 11 & 10.0 & 04 & 3.63 & 2.94 & $0.8,11.4$ & 0.06 \\
\hline Absent & 99 & 90.0 & 106 & 96.36 & 2.94 \\
\hline Total & 110 & 100.0 & 110 & 100.0 & & \\
\hline
\end{tabular}

Chi square $=3.5, \mathrm{P}=0.06, \mathrm{OR}=2.94, \mathrm{CI}=(0.8,11.4)$

It was observed that $11(10.0 \%)$ cases had history of ovulation induction in the study group and $4(3.63 \%)$ cases in the control group. The difference was statistically not significant $(\mathrm{p}=0.06)$.

TABLE 9: HISTORY OF TUBAL STERILIZATION

\begin{tabular}{|c|c|c|c|c|c|c|c|}
\hline $\begin{array}{l}\mathrm{H} / \mathrm{O} \text { Tubal } \\
\text { ligation }\end{array}$ & $\begin{array}{l}\text { Study group } \\
\mathrm{N}=110\end{array}$ & $\%$ & $\begin{array}{l}\text { Control } \\
\text { group } \\
\mathrm{N}=110 \\
\end{array}$ & $\%$ & OR & CI & $\mathrm{P}$ value \\
\hline Present & 11 & 10.0 & 1 & 0.91 & \multirow{3}{*}{12.11} & \multirow{3}{*}{$0.9,18.5$} & \multirow{3}{*}{0.001} \\
\hline Absent & 99 & 90.0 & 109 & 99.09 & & & \\
\hline Total & 110 & 100.0 & 110 & 100.00 & & & \\
\hline
\end{tabular}

Chi square value $=3.73, \mathrm{P}=0.001, \mathrm{OR}=12.11, \mathrm{CI}=(0.9,18.5)$

It was observed that there were $11(10.0 \%)$ cases who had undergone tubal ligation in the study group and 1 $(0.91 \%)$ cases in the control group and the difference was statistically significant $(\mathrm{p}=0.001)$.

TABLE 10: METHOD OF CONTRACEPTION USED

\begin{tabular}{|l|l|l|l|l|l|l|}
\hline $\begin{array}{l}\text { Method of } \\
\text { contraception used }\end{array}$ & $\begin{array}{l}\text { Study group } \\
\mathrm{N}=38\end{array}$ & $\%$ & $\begin{array}{l}\text { Control group } \\
\mathrm{N}=30\end{array}$ & $\%$ & OR & P value \\
\hline Barrier method & 22 & 20 & 25 & 22.72 & 0.85 & 0.73 \\
\hline OCPs & 08 & 7.27 & 03 & 2.72 & 2.7 & 0.12 \\
\hline IUCDs & 04 & 3.63 & 01 & 0.90 & 4.11 & 0.03 \\
\hline $\begin{array}{l}\text { Emergency } \\
\text { contraception }\end{array}$ & 04 & 3.63 & 00 & 00 & - & NA \\
\hline Injectables & 00 & 00 & 01 & 0.90 & - & NA \\
\hline Total number of cases & 38 & 34.54 & 30 & 27.27 & - & - \\
\hline
\end{tabular}

There were 38(34.54\%) cases who were using some method of contraception in the study group and 30 $(27.27 \%)$ in the control group. The difference was not statistically significant.

TABLE 11: HISTORY OF PREVIOUS LAPAROTOMY

\begin{tabular}{|c|c|c|c|c|c|c|}
\hline $\begin{array}{l}\text { Previous } \\
\text { laparotomy }\end{array}$ & $\begin{array}{l}\text { Study group } \\
\mathrm{N}=110\end{array}$ & $\%$ & $\begin{array}{l}\text { Control group } \\
\mathrm{N}=110\end{array}$ & $\%$ & OR & $\mathrm{P}$ value \\
\hline $\begin{array}{l}\mathrm{H} / \mathrm{o} \text { previous } \\
\text { laparotomy }\end{array}$ & 25 & 22.72 & 5 & 4.54 & \multirow{3}{*}{6.17} & \multirow{3}{*}{$<0.001$} \\
\hline $\begin{array}{l}\text { No h/o any } \\
\text { laparotomy }\end{array}$ & 85 & 77.27 & 105 & 95.45 & & \\
\hline Total & 110 & 100.0 & 110 & 100.0 & & \\
\hline
\end{tabular}


Chi square value was 13.87

It was observed that $25(22.72 \%)$ cases had previous history of laparotomy in the study group and 5 (4.54\%) cases in the control group. The difference was highly significant $(\mathrm{p}<0.001)$.

TABLE 12: PREVIOUS HISTORY OF ECTOPIC PREGNANCY

\begin{tabular}{|l|l|l|l|l|l|l|}
\hline $\begin{array}{l}\text { H/o previous } \\
\text { ectopic }\end{array}$ & $\begin{array}{l}\text { Study group } \\
\mathrm{N}=110\end{array}$ & $\%$ & $\begin{array}{l}\text { Control group } \\
\mathrm{N}=110\end{array}$ & $\%$ & OR & P value \\
\hline Present & 10 & 9.09 & 2 & 1.82 & \multirow{2}{*}{5.4} & \multirow{2}{*}{0.03} \\
\hline Absent & 100 & 90.91 & 108 & 98.18 & 100.0 & \\
\hline Total & 110 & 100.0 & 110 & & \\
\hline
\end{tabular}

Chi square value was $4.29, \mathrm{P}=0.03$, OR 5.4

Previous history of ectopic pregnancy was present in 10 (9.09\%) cases in the study group and $2(1.82 \%)$ cases in the control group. The previous history of ectopic pregnancy was statistically significant $(\mathrm{p}=0.03)$.

TABLE 15: PREVIOUS HISTORY OF ABORTION

\begin{tabular}{|l|l|l|l|l|l|l|}
\hline H/o abortion & $\begin{array}{l}\text { Study group } \\
\text { N=110 }\end{array}$ & $\%$ & $\begin{array}{l}\text { Control group } \\
\text { N=110 }\end{array}$ & $\%$ & OR & P value \\
\cline { 1 - 4 } Present & 38 & 34.54 & 20 & 18.18 & \multirow{2}{*}{2.37} & \multirow{2}{*}{0.005} \\
\hline Absent & 72 & 65.45 & 90 & 81.82 & 100.0 & \\
\hline Total & 110 & 100.0 & 110 & & \\
\hline
\end{tabular}

Chi test value is 3.03, P 0.005 , OR 2.37

It was observed that $38(34.54 \%)$ cases had history of prior abortion in the study group and $20(18.18 \%)$ cases in the control group. The difference was statistically significant $(\mathrm{p}=0.005)$.

\section{Discussion}

Over the past twenty five years there has been remarkable change in incidence, epidemiological factors, diagnostic methods and management protocols of ectopic pregnancy. Presence of various risk factors may strengthen the suspicion but their absence does not rule out ectopic pregnancy. Incidence of ectopic pregnancy in present study was 18.62 per 1,000 deliveries which was similar to studies conducted by Khaleeque F et al (2001)[3] and Anorlu RI et al (2005)[4] who found incidence of 13.22 and 23.1 per 1,000 deliveries, respectively.

Mean age of cases in the present study was 28.72 years which was comparable to the studies conducted by Anorlu RI et al(2005)[4] and Kopani et al(2010)[5], they found mean age 27.8 \pm 6.21 years and 30.38 years respectively. The present study found that the ectopic pregnancy was common among multigravidae and seen in 80.90\% cases which were in concurrence with the study conducted by Panchal D et al (2011)[6], who noticed ectopic pregnancy in $81.66 \%$ multigravida women.

The studies conducted by Handler A et al(1989)[7], Coste J et al(1991)[8] and Bouyer J et al(2003)[9] has showed that history of smoking was present in $38.30 \%, 40.14 \%$ and $58.53 \%$ cases respectively which was not comparable to the present study. This could be attributed to regional and socio-economic factors.

History of multiple sexual partners was present in $6.36 \%$ cases in the present study which was not in concurrence with the studies by Bouyer J et al(2003)[9] and Anorlu R I et al(2005)[4] who found history of multiple sexual partners in $75 \%$ and $68 \%$ cases respectively. This could be due to differences in the regional and socio-cultural factors.

H/o PID was associated in $22.70 \%$ cases in the present study which was comparable to the study conducted by Hassan N et al (2009)[10], who found PID in 35.4\% cases.

Present study showed history infertility in $23.60 \%$ cases which was comparable to the study conducted by Bouyer $\mathrm{J}$ et al (2003)[9], who found infertility in 30.13\% cases. H/o ovulation induction drug use was noticed in $10 \%$ cases in the present study which was also similar to study by Khaleeque R F et al(2001)[3], who noticed $\mathrm{H} / \mathrm{o}$ ovulation induction in $10.3 \%$ cases.

$\mathrm{H} / \mathrm{o}$ tubal sterilization was found in $10 \%$ cases in the present study which was similar to results shown by Raviprabha et al(1994) [11] and Majhi AK et al(2007)[12] who found H/o tubal sterilization in $10.83 \%$ and $14.4 \%$ cases, respectively.

$\mathrm{H} / \mathrm{o}$ tuboplasty was present in $2.70 \%$ cases which was at variance to studies conducted by Nordenskjold F et al(1991)[13] and Bouyer J et al(2003)[9] which could be due to the fact that very few patients opt for tuboplasty in Himachal Pradesh.

The study conducted by Khaleeque RF et al (2001)[3] who found H/o IUCD use in 5.1\% cases was in concurrence with the present study.

The studies conducted by Anorlu RI et al(2005)[4] and Hassan N et al(2009) [10] found that the previous history of laparotomy for various indications was present in $23 \%$ and $26 \%$ cases respectively which was similar to result shown by present study $(22.72 \%)$ cases. 
Previous ectopic pregnancy was present in $9.09 \%$ cases in the present study which was similar to results shown by Hassan $\mathrm{N}$ et al (6.45\%) [10] and Abbas A et al(7.40\%) [14] cases respectively.

The studies conducted by Majhi A K et al(2007)[12] and Aziz S et al (2011)[15] observed prior abortion in $26.1 \%$ and $37.8 \%$ cases respectively, which was in concurrence to the present study (34.5\%) cases.

\section{Conclusion}

Ectopic pregnancy still remains the most lethal obstetrical emergency so a very high index of suspicion in women with risk factors will reduce ectopic pregnancy related morbidity and mortality because of early diagnosis and timely management. Increased incidence of ectopic pregnancy was attributed to increased incidence of IUCD use, PID, abortions, infertility and more laparotomies for various indications. More studies are needed to explore further risk factors to reduce prevalence of ectopic pregnancy.

\section{References}

[1]. Rock JA, Jones HW. Ectopic Pregnancy. In: Te Linde's Operative Gynecology. 10 ${ }^{\text {th }}$ ed. New Delhi: Wolters Kluwer Publication Pvt. Ltd; 2008; p.798-22.

[2]. Cunninghum FG, Leveno KJ, Bloom SL, Hauth JC, Rouse DJ, Spong CY. Ectopic Pregnancy. In: Williams Obstetrics. 23 ${ }^{\text {rd }}$ ed. United States of America: Mc Graw Hills Publishing; 2010; p.238-54.

[3] Khaleeque F, Siddiqui RI and Jafarey SN. Ectopic Pregnancy: A Three year study. JPMA 2001; 51: 240-44.

[4]. Anorlu RI, Oluwole A, Abudu OO and Adebajo S. Risk Factors for Ectopic Pregnancy in Lagos, Nigeria. Acta Obstet Gynecol Scand 2005; 84:184-88.

[5]. Kopani F, Rrugia A and Manoku N. Ectopic pregnancy comparison of different treatments. Journal of Prenatal Medicine 2010; 4(2): 30-34.

[6]. Panchal D, Vaishnav G and Solanki K. Study of Management in patient with Ectopic Pregnancy. NJIRM 2011; 2 (3): 91-94.

[7]. Handler A, Davis F, Ferre C and Yeko T. The relationship of smoking and ectopic pregnancy. Am J Public Health 1989; 79 :1239 1242.

[8]. Coste J, Job- Spira N, Fernandez H, Papiernik E and Spira A. Risk Factors for Ectopic Pregnancy: A Case Control Study in France, with Special Focus on Infectious Factors. American Journal of Epidemiology 1991; 133(9): 839-49.

[9]. Bouyer J et al. Risk Factors for Ectopic Pregnancy: A Comprehensive Analysis Based on a Large Case Control, Population -based Study in France. Am J Epidemiol 2003; 157:185- 194.

[10]. Hassan N, Zaheen Z, Jatoi N, Srichand P and Shaikh F. Risk factors, Clinical presentations and Management of 62 Cases of Ectopic Pregnancy at Tertiary Care Centre. JLUMHS 2009; 08(3):238-41.

[11]. Raviprabha, Kalshreshtha, Ectopic pregnancy and fertility control measures. The J of O \& G India 1994; 44(5): 70-4.

[12]. Majhi AK, Roy N, Karmakar KS and Banerjee PK. Ectopic Pregnancy- an analysis of 180 cases. J Indian Med Assoc. 2007; 105(6): 308-312.

[13]. Nordenskjold F and Ahlgren M. Risk Factors for Ectopic Pregnancy: Results of a population based case control study. Acta Obstet Gynecol Scand 1991; 70: 575-79.

[14]. Abbas A and Akram H. Ectopic Pregnancy: Audit at Maula Bakhsh Teaching Hospital Sargodha. Professional Med J 2011; 18 (1): 24-27.

[15]. Aziz S, Wafi B I and Swadi HAI. Frequency of ectopic pregnancy in a Medical Centre, Kingdom of Saudi Arabia. JPMA 2001; 61: 221-224. 